\title{
急性放射線障害モルモツトの骨㵦酸素消費と 骨噃乾燥粉末注射に関する知見
}

The Oxikdtion Rate of Bone Marrow in Acutely Irradiated Guinea Pigs and the Effects of the Injection of Pownered Bone Marrow

\author{
加藤 松 次 郎* \\ Matsujirō KAT̄̄
}

\section{緒誵}

時代の影響を受壮近時放射線障害特に急性放射線障害 の研究が盛んになり, 并の全身障害の主変が造血臟器て あるので研究も多くはこの方面何向けられ，始めの形態 学的血液学上り濑次脱却し, 生化学的機能的方面に研究 が進められて来た ${ }^{11}$ ，沿潦法としても，或程度効果あり と報告されている楽剂も相当数あるが, 未だ充分の成果 をあげ得るものは見当らない。

$\mathrm{X}$ 線照射の際渒臟, 尾等身体の一部忌被覆して掠 く之死亡率少く, 生存日数が長いことから, 種々の動物 臟器の移植や臓器乳剂が效果市り之されている。例兄ば 致死量の X 線全身照射マウスに同程幼弱動物の脾 歲2) 3) 23) や骨䯣 3) 4) 22) 24) のエムルデオンを注射する

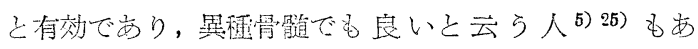

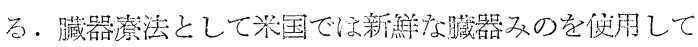

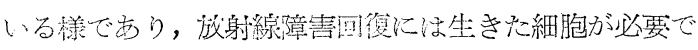
あると述べている報告もあるが，この効果学岩川教授は 是等臟器細胞中の何等かの成分が造血臟器を刺战鼓舞さ せるのが主因で，必ずしも生きた細胞を必要としないと

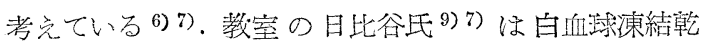
燥枌末の浮遊液双は先の水浸液の注射水間及動物の未 䊑血液中の白血践增加作用があることをみてこの浮遊液 をX線照射マウスに筋注して急性放射線障害に対する治 療効果を報告している. 矢追氏等 ${ }^{8)}$ は X 線照射マウス に精製痘苗を連日皮下注射し，死亡率及組織学的に見て 効果あることを発表しているが，この際ウイルスを殺し た不活化精製痘苗でも少し注射量を堌せば同樣の効果を 得て括り，更に艺の有效成分学追求乙て所謂螢白部分に その效巢を認めず，核酸成分が需瑟な役割を演ずること を報じている。

私法急性放射線障管動物の骨噵酸素消費量の面より， 日比谷氏 9）の白血球粉末の効果をしらべ，更に白血球

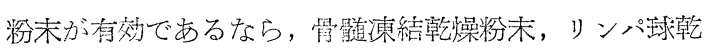

* 順天堂大学医学部小罗科学教室 1960 年 4 月 14 日受付
燥粉末も又何等かの治潦効果ありと考えて, 主として骨 䯣呼吸作用の面より検討し若干の知見を得たので報告す る。

\section{実 験 方 法}

1. 実験動物：購入後 7 日間以上一定飼料で養育した 体重 $550 \mathrm{~g}$ 前後のモルモットを使用した. 赤血球数 500 \pm 80 万, 白血球数 $7500 \pm 1500$ 以内, リンパ腺腫張を認 めないものを選んだ。

2. 検血：モルモットの検血は頸動脈学切り, 即殺し たときに採取し，通常の血算潐じて行つた。

3. 骨䯣懸濁液： 頸動脈切斨で即殺したモルモットの 大腿骨を関節面で離断, メスで割り, 滅菌ペニシリン注 射針で骨䯣組織を丁寧に剝離採取した。1 匹の大腿骨よ

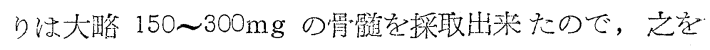
計量した後，4cc の Krebs-Ringer-Phosphate 液 (以 下 K.R.P 液) に入れ，ガラス製ホモゲナイザーデ粗に ホモゲナイズして骨髄懸濁液とした。

K.R.P 液の組成は

$\begin{array}{lr}0.90 \% \mathrm{NaCl} & 100 \mathrm{cc} \\ 1.15 \% \mathrm{KCl} & 4 \mathrm{cc} \\ 1.22 \% \mathrm{CuCl}_{2} & 3 \mathrm{cc} \\ 2.11 \% \mathrm{KH}_{2} \mathrm{PO}_{4} & 1 \mathrm{cc} \\ 3.82 \% \mathrm{MgSO}_{4}, \cdot 7 \mathrm{H}_{2} \mathrm{O} & 1 \mathrm{cc} \\ 0.1 \mathrm{M} \text { 燐酸緩衝液 } & 12 \mathrm{cc}\end{array}$

（但し，採取した骨䯣を直接入れるるのには予め $2 \%$ の割に血沈用クエン酸ソーダを㸝光, 検圧計側室には $\mathrm{M} / 10$ ブドー精添加液を用いた）K.R.P 液を用いたの

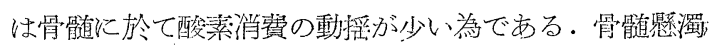
液の水菜イオン濃度は $\mathrm{pH} 7.4$ 飞一定した。これは $\mathrm{pH}$ 7.1〜7.4の間では骨䯣の呼吸解糖作用は信頼度 $99 \%$ 以 上と云う上原氏等 $\left.{ }^{10)} 11\right)$ の報告炕集じてものである.

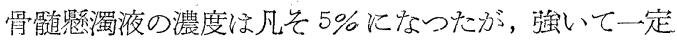
にせず後で骨䯣の新鮮重量 $\mathrm{mg}$ 当りに換算した。しか

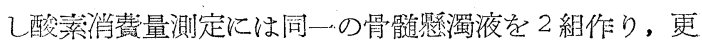
飞 K.R.P 液で, $1 / 2$ 及び $1 / 3$ 稀釈度の骨䯣液も作り, 
同時に検圧器にかけて測定し, 検算に供して誤差なきを 期した，

4. X 線照射：二次電压 $100 \mathrm{KV}$, 二次電流 $3 \mathrm{~mA}$ で, $3 \mathrm{~mm}$ アルミニウムの濾逅板を通し，300rの X 線照 射をモルモットル1回全身照㧭した。

5. 幻弱家鬼骨髉凍結乾燥枌末の作成：幻弱家鬼（生 後1 力月）の大腿骨を割り骨髄をはがして出し，小量の 生理的食塩水を加光て, 簡単に遠儿分離して上贋部（脂 肪分) を除さ直名に凍結乾燥した。乾燥器は骨髄組織を 少量づつアンプルに入れて,一コづつ直援遵管に接続す る多歧管式 (Manifoldtype) を用いた。 之は重:菌操作 分容易で一次的に真空熔封が出来るためである 12)13)。骨

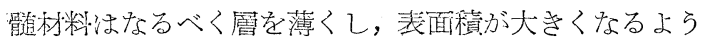
にして凍結した。凍結乾燥した骨䯣は父のまま封入し， 詅暗低温に保有した。注射に際してはこの翰燥粉末を蒸 溜水でとき，㲘濁液としてそのまま注射した。

6. 成熟豚骨䯣の凍結乾燥粉末：家䖝骨髄と同様の方 法で涷結乾燥し, 蒸溜水で奬濁液として用いた。

7. 白自球粉末：乾燥血獎を作る工場で採血し $4^{\circ} \mathrm{C}$ に24 時間乃至 48 時間静置 した ACD 液加人間血液は

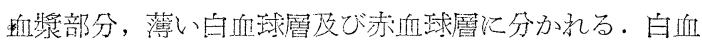
球膡部を吸いとり，生理的食塩水儿䝮濁して遠心して出

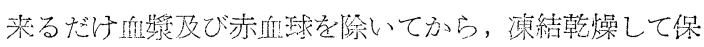
存した。

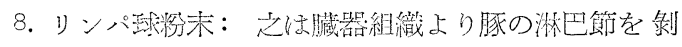
離して割り, 去の内容を採取した。この淋巴球液（リン ハㅇ節内容 4：生理的食塩水 1) には 20eckつきストマ イ $0.1 \mathrm{~g}$ を添批，以下骨髄と全く同栐な方法で涷結乾燥 した。

\section{実 験 成 績}

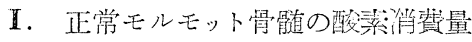

家虫骨䯣のワールブルグ氏検圧法による酸亲消費量の 報告性多く，最近では上原，国延氏等10) が埰告してい るが，モルモットについて手許の文献に見あたらず，且

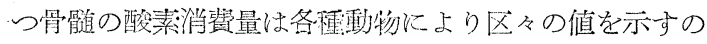

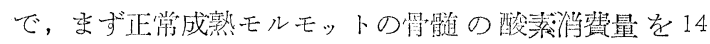
匹について測定して見た。炎の值を図1の左端儿示した

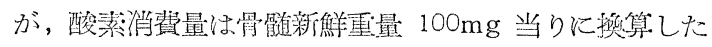

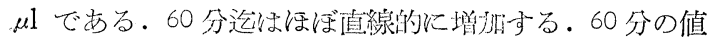

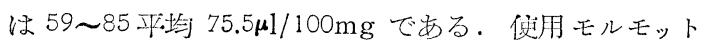

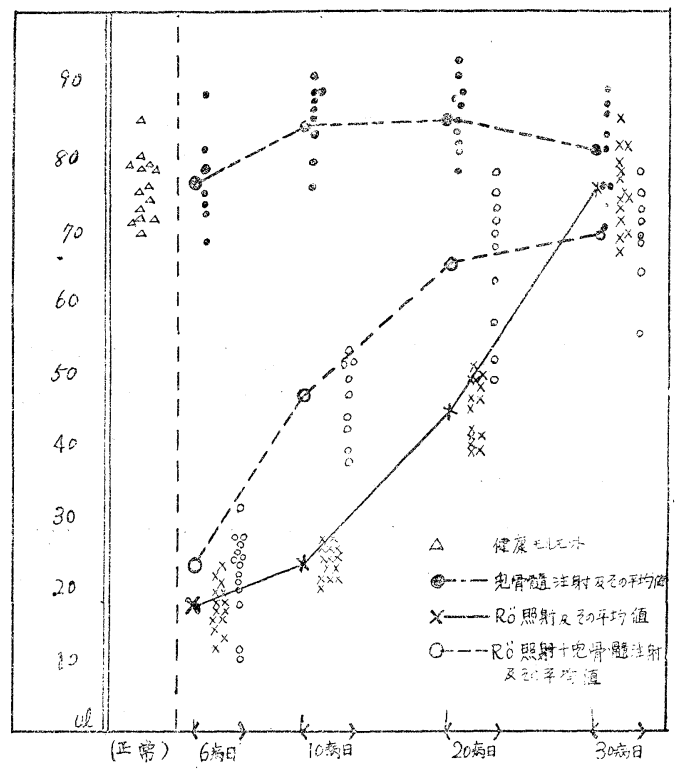

図1モルモット骨随の酸素消費量 (骨随 $100 \mathrm{mg}$ 当り 1 時間值)

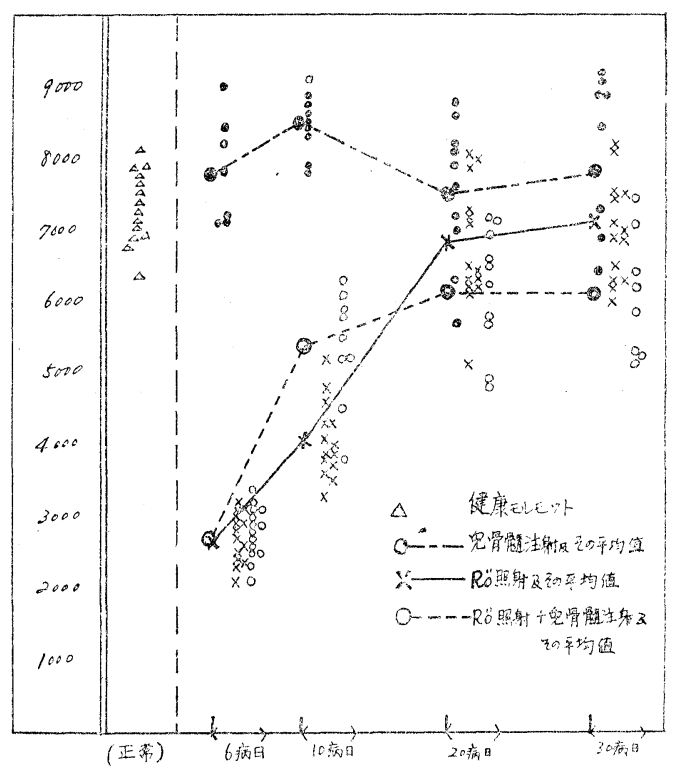

図 2 モルモットの白血球総数 の末梢血の白血球数, 赤血球数, 血色素值は図 2,3 に 示した。 


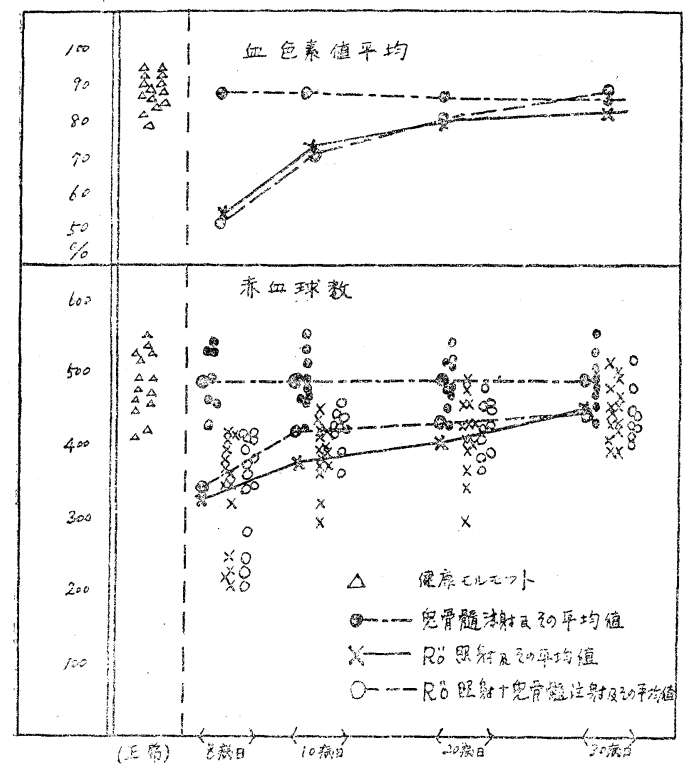

图3モルモット赤血球数及び血色素值 (ザーリー值)

II. 家鬼骨髄乾燥汾末注射モルモツト

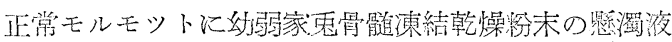
(新解骨䯣として $50 \mathrm{mg}$ 含有)を锤日皮下に注射して

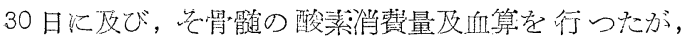

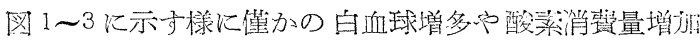
を認めたものがあつたが全体として著变はなかつた。

III. 急性 $\mathrm{X}$ 線㖏碍モルモツト

300r 全体一回照射したモルモツトの変化と恢復邀程 を知る為飞, 第 6 病日, 第 10 病日, 第 20 病日, 第 30 病日に夫々 14 匹づつについて血算や骨䯣酸亲消責量を 測定した成績は図 1〜3に示す，何れの価も第6 病日に 䧉著明に少く, 先の次㥞第に回復し, 白血球数及び血色 素值は第20病日頃, 赤血球数及び骨䯣酸䒺消賔量は第30 病日頃に正常值にもどる例が多い，多くの報告で $\mathrm{X}$ 線 障碍の回復の目標とされている末䊑血白血球総数が㴗淰

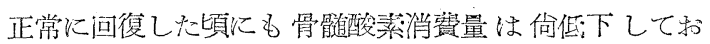
り，10日位る抏くれて正常值にもどることがわからた。 各病日のモルモットの骨髄酸素消費量值について個体差 を考慮して最高值之最但值をとり，当绫病日の酸素消費 量の变動の籁囲を推測してみると図 4 の如くなり, 個体 差を考慮しても各病日の酸素消費量の箸田が殆んど交錯 することなく回復してゆくことがわかる。

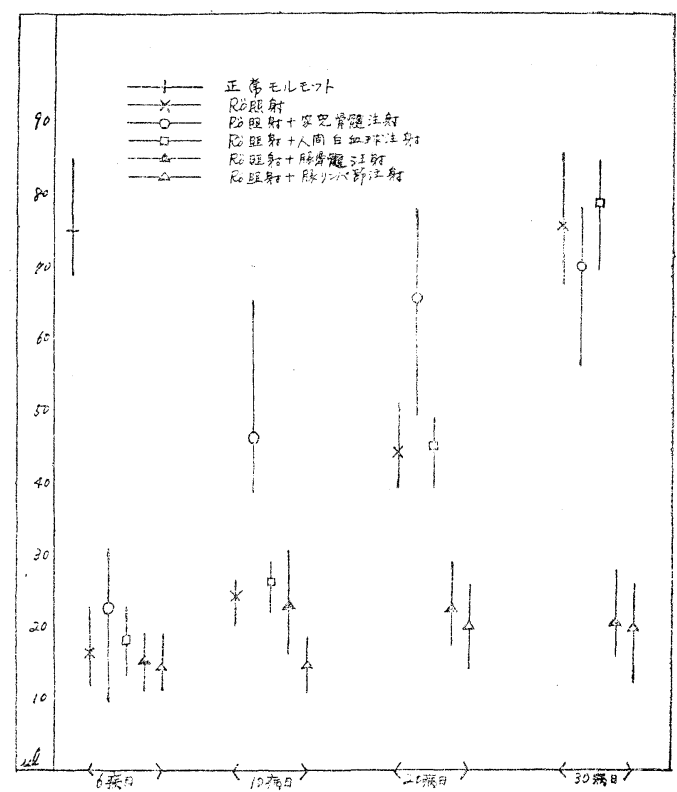

图4モルモット骨髓酸溸消量の各最高最 低值及びその平均値

（骨随 $100 \mathrm{mg}$ 当り 1 時闌值）

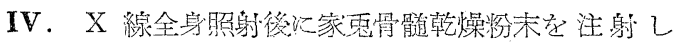
たモルモツト

同㥞に $300 \%$ 全㐞一回照射したモルモットに, 幼弱家

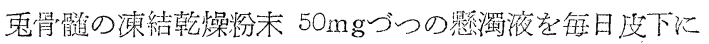
注射して, 対照群と同じく, 第6, 第 10 , 第 20 及び第

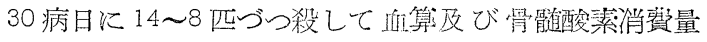
を测定し, 図1〜3及び図4 に示した。全べての測定值 は第6病日には著明に低下し艾の後回復して行くが, 赤

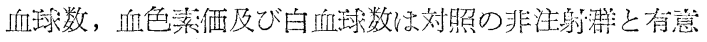
の差を示さなかつた。(第6病日の白血球数の平坛は注 射据沉多いが，撨計学的には有意の差ではなからた）之 に反し, 骨䯣酸素消費量で攺第10病日で注射群は非注 射群より有意に高く，第20病日で既に 10 匹中 6 匹は正 常值に回復していた，既ら $\mathrm{X}$ 線全身炤射後芜贯骨髄

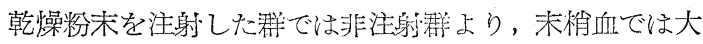
差ないが，骨䯣酸素消蒷量で見ると有意に早く回復す 万.

V. 豚骨䯣粉末注射モルモツト

300r 全身 1 回照射したモルモットに成熟豚骨䯣の凍 結乾燥粉末 $50 \mathrm{mg}$ の渻濁液を每日皮下に注射した群よ り第 6,10,20 及び 30 病日に 5 匹づつ殺して, 血算並に 骨䯣酸素消費量を測定すると図 4 5 の如く，第6 病日 


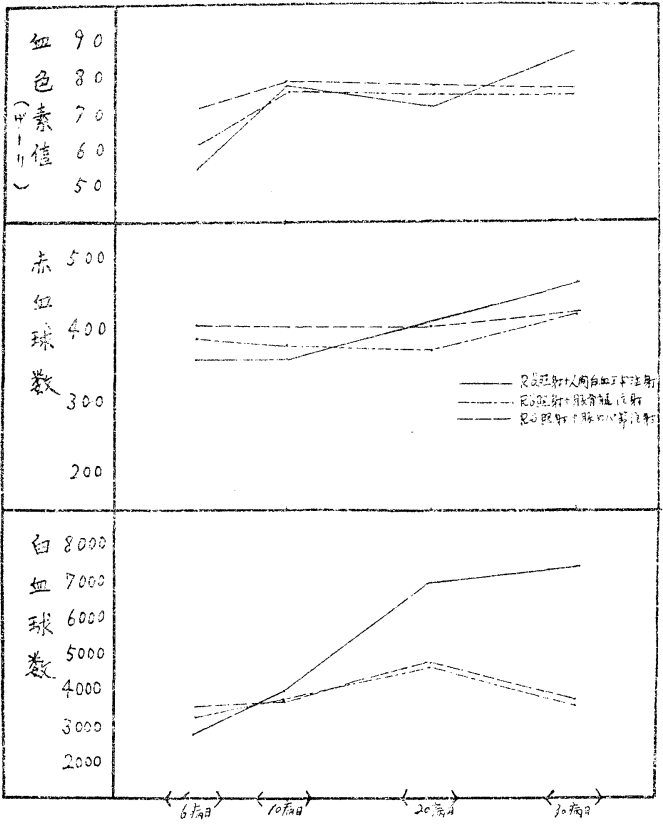

図 $5 \mathrm{X}$ 線 照射モルモツト各血算平均值

(人白血球，成熟豚の骨䯣，リンパ球各粉末注射）

飞低下した各数值が 20 日だつても，30日たつてるほ とんぞ回復しない，モルモットはや忧す来て备所りンパ 腺が高度に腫脹して来た。

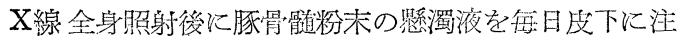
射すると，血算及び骨䯣酸美消費の何れから見ても正常 值への回復が甚だ崌い。

VI. 豚リンパ球粉末注射モルモツト

前記と全く同様な X線 照射モルモットに成熟豚リンパ 球の涷結乾燥粉末 $50 \mathrm{mg}$ の憘濁液を每日皮下注射 した 群上り，第 $6,10,20$ 及び 30 病日に 5 匹づつ殺 して测 定した血算並びに骨䯣酸素消費量は豚骨髓注射の場合々 相似し，図4〜5の如くなつた。

VII. 人白血球粉末注射モルモット

同滕のX線照射モルモットに人白血球粉末 $50 \mathrm{mg}$ の

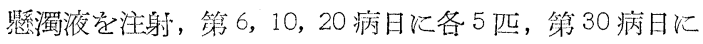

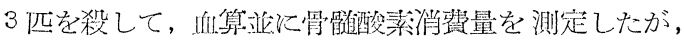
図 4〜5 の如く著変を誌めず，同様の $\mathrm{X}$ 紹照射モルモッ トの非注射涪: (図 1〜3) 之暞似した数值定示した。対 照群としてX線照射を行わず注射をしたモルモットに 於ては豚骨䯣反び豚りンパ球の涷結枌末学注射した群で

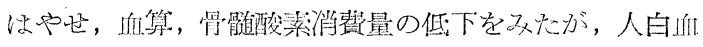

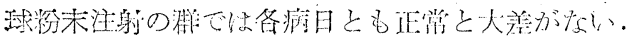

\section{考挖}

X 線照射以上る血液細胞, 骨䯣の変化については Heineke (1905) 14) 以来多数の研究涬告が市门，大絧 は明らかに皇つているが，詳細については成績の一致し ない点も少なくない，実験動物によつても多少の差があ り，マウス，家息，犬についての実験は多いが，モルモ ットに関しては必ずしも多くない，私は骨䯣の酸㨞消費 量を測定する為にモルモットを便用したので，主として モルモットル300 r 1 回全身照射した実験成漬を参照す る.

モルモットに 300 1 回全身照射した埃合の末梢血液 の変化については, 福島氏 15) は体重 260 600g のモ ルモツト6例照射し, 赤血球数, 血色菜量は動摇が大 きく一定の傾向を確認出来なからたが 7 20日目には隇 少例多く, 生存した例では再び增加乙照射後 38 日目頃 には正常になつたと云う。前田旦 ${ }^{17}$ ) は休重 $400 \mathrm{~g}$ 以上 のモルモットにつき 5,10,50/day 照雅群の实騟結果よ り，24 時間の前田氐 ${ }^{17)}$ は体重 $400 \mathrm{~g}$ 以上のモルモッ 卜連続 1 回照射 $(5 \mathrm{r} / \mathrm{min}$, 又は $1 / / \mathrm{min})$ で, $250 \gamma$ で

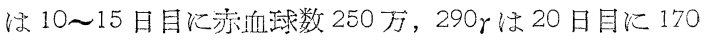
历゙になり，25〜30日で正常值にもどつているので, 斯

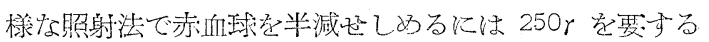
と推定している.

Lorenz ${ }^{18)}$ がモルモットのX線障害死性資血炕よるも のであると云つている様に，モルモットが X 綠筫近 を起しやすいこと蛙人ょく類にて扬り,一時照射に上 りモルモットの半数を死亡させる X 線量 ( $\left.L D_{50}\right)$ は 約 $310 \gamma$ と云われ, 人類で約 $400 \gamma$ と云われるのと大

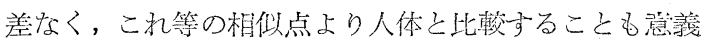
があると思う ${ }^{17) 。}$

私も $\mathrm{LD}_{\varepsilon_{0}}$ を目骠に $300 \gamma 1$ 回全身照射をしたのであ るが，図 3 の如く，個体差は大きいが赤血践数正常值 420 560 万平域 490 万が第6 病日に 200 430 万平均 330 万と約 $3 / 5$ 亿減少し, 第 20 病日で大部分正常值飞 もどつているのは上記諸氏の竬告付大体合つている。こ

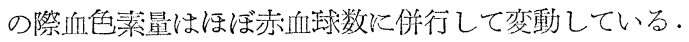

赤血球数及び血色素量より久る場合には幼弱寻家覌骨䯣 枌末连続注射怔常及び X 線照射モルモットの活者

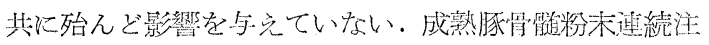
射ては図 1 の如く，X線照射で但下した赤血球数及び血。 色䇣量の恢復を殆んど止わてしまう。

白血球数の変動で見ると, 福島氏 ${ }^{15)}$ の300 r 照射祥 では照射後 30〜270 時間で何れも白血球数が著減し，特 に先の後半に最低值を示す例が多く，320４90 時間で 
白血球数が增㧈に転じ 30 40 日で正常值に回復 した。 前田氏 17) の赛騟で血球减少曲線恃赤血珠惊 Sigmoid, 白血琲はexponentialの如き形を示し，赤血球数が Sigmoid の平坛值である 50\%を示す時期汇白血球数も亦 exponentialの平坛値である $37 \%$ 亿近い値を示するのが

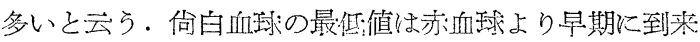
する. 350 r (24 時間分散照射) では2 15日飞2000〜 4000 の最但値を示し 25 日〜 60日で恢復し，250r（24 時間分散照射）では 2〜15 日約 3000 になり 40 日位で回 復している. $5 r / \mathrm{min}$ 連続1回照射では $250 r$ 及び $290 \gamma$ 各 1 例づつで5〜12 日に 1500〜2000 の最低值を示し， 30 日又恃先扎後に回復している。

私の例では図 2 の如く6病日で 2000 3200 平坛 2700 と約 36\% に減少し，20病日に大部分が正常值にもどつ た。幼弱家躳骨䯣粉末注射では正常モルモットの血冰 数を少乙增加させた例があり，X線照射6 病日の白血球 数を增加させた例もあるが全体として，両者の白血球数 に余り影響を与兄ていない。豚骨䯣粉末注射はX線照 射で減少した白血球回復を著しく抑制する。

骨䯣の変化子Heineke ${ }^{14)}$ 以来形態血液学的には多 数の研究があり, 照射後数時間で血液細胞の個々に各種 の変性反応が見ら水，48 時間後頃より細胞数の著明な 減少が起り，顆粒細胞系ついで赤血球系が共に先の灯若 型がまず消失する。4〜 病日に最高度になり，骨䯣は 荒廃し，主に網状組織細胞のみにより占められ血液細胞 は殆んど見られない。この時期が過ぎると再生現像が始 末り, 赤血球の再生の方が顆粒細胞より早く抢こつてく るらしい. 14)16)19)20221)

骨䯣は放射能に敏感で X 線照射で障害を受け易いこ とは良く知られて呿り，一方骨䯠は呼吸作用の大なる組 織であるから, 艺の酸素消賽作用は X 線障害に際し, 強く低下乙実貿細胞の再生に伴い回復することが考兄ら 孔る。骨䯣細胞数や形態学的変化先立つて機能的生化 学的変化が現われるはづであるがこの方面の研究は未だ 少く, 骨䯣酸素消費量の面から X 線障害や艺の恢復程 度を研究した報告は泀とんど見あたらない。

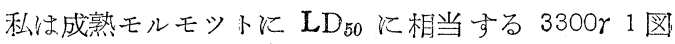
全身照射をして，炎の骨䯣酸素消費量の変化をしらべ た。勰濁液にしてワールブルグ氏検圷計で $37.5^{\circ} \mathrm{C}, 60$ 分の振渴照で酸素消費量は新鮮重量 $100 \mathrm{mg}$ 当りに换算-す ると, 正常値は 69〜85 平均 $75.5 \mu 1$ であるが, 照射後 3,4 日には殆えど測定出来ない程低下乙, 第6 病日では 12〜23 平均 $17.5 \mu 1$ と 1/4 以下に低下して和り, 赤血球 数及び血色素量が約 $3 / 5$ 亿白血球数が約 $3 / 8$ 亿低下して
いるのに比べ，但:下が著明であり，兄の後ほぼ直線的に 回復し 30 日前後で正常值にもどつている. 従つて放射 線障害の程度及び恢復状態をみる為に骨䯣酸素消費量を 湘定することは甚だ有意義で, 赤血球数, 血色素量や白 血球数より敏感である.この骨骴酸素消費量を目標沉し

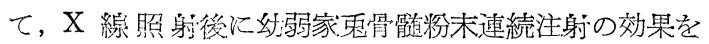
見ると図 1 の如く, 第 10 病日及び 第 20 病日で注射群 で虻有意に骨䯣酸菜消費量が多く, 障害よりの回復の早 いことを示している。しかるに豚骨䯣粉末の注射では第 10〜30 病日の酸菜消費量が殆んぞ上等吼ず, X 線障害 よりの回復を阻害していることがうかがわれる。（図 4)

結局 X 線大量 1 回照射後飞幼弱家朿骨䯣粉末を $50 \mathrm{mg}$ づつ連日注射すると障害回復を或程度促進する が，豚骨䯣粉末を同量注射すると逆に回復を著明に阻害 することがわからた。

一般にX 線照射の生体に欧济寸作用は直接及び間 接の 2 種が考光られ, 直接作用として少量では臟器組織 飞刺㦸作用を有し，中等量或は大量では破壊作用を有す ると考兄られている。矢の直接作用によつて被照射臓器 組織成分が変性を来し, 血流中游出して諸灆、器組織比 非特異的刺㦸作用を巷起起し，先の刺战が適度の場合 飞恰已蛋白体潦法の如く細胞賦活的飞作用乙，過度の 場合は中塹的变性破㯰的纪作用する. 22)23 24;32) 次いで

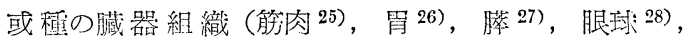
肝 29) 等) の変性組織成分に対しては自家抗体（即ら細 胞羑素が産生されて, これら自家抗体は当該臓器組織水 特異的に反応して先の臟器㙨能を或程度障碍するとされ ている. ${ }^{23) 30)}$

骨䯣に関しては Lutwak-mann ${ }^{31)}$ 等は家种に 1000\%， ダイコクネズミに 500 ○を昭射した直後には骨䯣の解:䄷 呼吸作用には変化なく，3〜6日後になつて但下したと 云つて X 線照射の間接作用の重要性を暗示し，その 他骨髄に対なる関接作用については $\mathrm{H}_{\mathrm{sii}} \mathrm{Ma}^{33)}$ は非照 身部の骨髓に代償性の增殖竟見たいといい，Barns ${ }^{34) ，}$

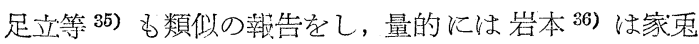
で非照射部位では 200 万では恋化を見ず，500 でて增 扣し，1000〜3000 では3〜14 日目迄骨㖪細胞增加し，

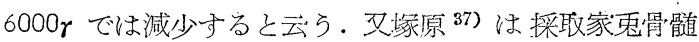
に直接 X 線照射すると骨䯣は変性し, 之家鬼に注 入すると注入された家匤の骨䯣も障害されることをみて いる。

一方金生 ${ }^{38)}$ は家种骨䯣 X 線照射で，被照射骨䯣 よりの成分が血液像先の他淑響を与兄るが，关れに対 
する自冢抗体は証明出来ないと云ら。

$\mathrm{X}$ 線照射により生体内に剌㦸及び至中毒物筫が産生 されることを証明した報告虫多数あるが，その物筫につ いて Helber 等 ${ }^{89)}$, Deptovic ${ }^{40)}$, 渡辺 ${ }^{41)}$, 脇本 ${ }^{42)}$ 等 は白血球の破壞産物を証明しているが，その㑁つ由来を 瓡告している人も多い。照射動物の血液中より結晶性ポ リペプチド 43)44）旮の低作用物筫をとり出した報告もあ る.

$\mathrm{X}$ 線照射障害に細胞成分のエムルジオンを注射し て効果を認めた報告には Lorenz 等4)18) Trentin 45) 等次第に多くなつた.

Trentin はマウスに LD 100 以上の 770 r 全身照射後 同種骨髄と異檑マウス咀髄を混じたものを静注すると， 生存率及び体重減少は対照に比べ著明な効果があつたと 小ら.

我国でも2,3 の追記があり，佐々木 ${ }^{46)}$ 等も600r 全 身照射ラッテに健常ラッテの骨䯣成分を注入した例は照 射のみの対照例に比し, 骨䯣の細胞密度, 未梢血の白血 球総数及び網状赤血球の百分比に著しい䁌加を, 脾, 胸 腺ならびに胸腺，リンパ組織に和訂る有核細胞総数の增 加を見ている。

一方骨髄細胞成分を淔接健康動物に注身して去の変化 をしらべたのには, 㗬川教授阴下の大野47) が同種骨髄 乳郕を動物に 1 回注射する時はその少量では骨髄に刺㦸 的に作用し，大量では赤血球の減少を来すことを認め， 宫川教授のアウトホルモン説に於ける所謂直接作用によ るものとし, 大島 ${ }^{48)}$ b家鬼自家骨䯣成分溶液の連続注 射の血液所見により，之に同意している。乙かし，棚 橋 49) は家悲骨䯚成分融解液の大量を家鶏に連続注射し て血液像をみると, 初期に著明の变化を来さず, 各種細 胞は増加の傾向さ京したが, その後約 1 週間後には漸 次貧血を来したので, 注射直後の变化は悹川教授の所謂 值接作用によるものならんも, 艺の後の変化は自己体内 で作られた扮自家骨䯣血清が作用したものならんと云つ ていたが，金生 ${ }^{33)}$ は被 X 線照射家象骨䯣細胞浮遊液 又はエキスを抗原として棰々の方法で健康家鬼を㑆疫し ても被 X 線照射骨髉に刘する自家抗体産生を血清学 的に証明できなからた。

私の実験では $\mathrm{X}$ 線つ大量全身照射したモルモット

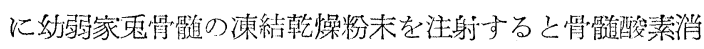
費量の回復を促焦することがわかつた。この場合前記文 献つ照射動物に骨髄細胞を注入した時と同樈の作用があ つたと推定出来る。即ち骨髓細胞エムルジオン或は骨髉 凍結乾燥を作る操作により軽い变性を受けた細胞成分が
照射動物の骨髄を軽く刺㦸し，宮川教授の所謂直接作用 により骨髄の機能を促進せしぬたものと思われる.

この場合にも注入した骨䯣粉末に対する抗体が出現し て作用することも考え得るが，前記金生 ${ }^{38 ）}$ の実験にあ る様に骨䯣は比較的抗体を作りにくいので抗体の作用は 少小もの之相像される. 一方 X 線大量照射により生 体は扮体産生能が甚だ但下乙, 只こに新鮮異䄸骨髄注射 をしても抗体産生が微弱であることが知られているの で, 乾燥骨髄粉末では一鰨抗体産生が少くなかつたと思 われる. Lorenz 等 (1954) 18)50) は新鮮骨盛を用いて も異種動物の骨䯣移植に成功したと云う。

教室の日比谷 7) はマウスの急性 X 線障悪に人白血球 乾燥粉末を反復注射すると, 死亡摔を著明低下させ, 末梢血液像の回復を促寸ことをみて和り，松村31は此 際に骨䯣像をしらべ, 骨䯣細胞の減少も軽く, 回復も早 いことをみている。しかて私が，X線照射モルモットに 人白血球粉末を注射した場合には回復に效果がみられな からた。

一方同量の豚骨髄凍結乾懆汾末を注射した場合に逆に 回復を強く抑制したのは, 注射量が多過ぎた為か, 動物 の差が，或は便用動物が灯弱之成熟であつた為か，何れ

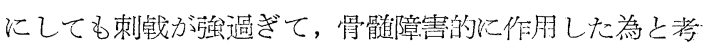
えられるが更に研究を覆する点である。

\section{結論}

成熟モルモットに300r 1 回全身照射を行つて急性 $\mathrm{X}$ 線障害を起し, それに幻弱家鬼骨骨道凍結乾燥粉末， 成熟豚骨䯣凍結乾燥粉粉末，成熟豚リンパ栨涷結乾燥粉 末及び人白血注冰凍結乾燥粉末の德日注射を行い，主に骨 䯣酸美消費量を測定して次の結果を得た。

1. X 線全身照射によりモルモットの骨喸酸素消費 量は著明に低下し，末梢血赤血球数，血色素量及び白血 珠擞より住下度が强く, ほぼ直線的に回復するので, $\mathrm{X}$ 線障碍の程度, 回復の状態をしらべるのに骨髉酸素

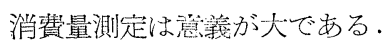

2. 急性 $\mathrm{X}$ 線障害モルモットに幻弱家雸骨骴涷結乾 燥粉末を連日注射すると, 血色素量, 赤血球数及び白血 非数では著変がないが, 骨骮酸素消蕒量の问復を有意に 促進する。

3. 急性: X 線障害モルモットに成熟豚骨骵凍結乾燥 粉末を軏日注射すること, 未梢向，赤血政数，血色䇣

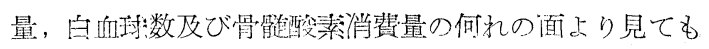
障畫回復を著しく阻害すする。

4. 急性 $\mathrm{X}$ 線障雪モルモットに成熟豚りンパ醇涷結 
乾燥粉末を連日注射した場合子成熟豚骨骵凍結乾燥粉末 を注射した場合と略々同じ成績である。

5. 急性線X障害モルモットに人白血稳涷結乾懆粉末を 連日注射老行つた場合には, 赤血永擞, 血色素量, 白血

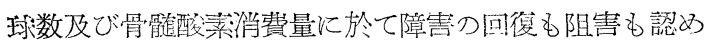
られなかつた。

擱等に当り, 御指導, 御校閲を賜つた岩川克信教 授に感謝の意を表し, 御援助を戴いた関根隆光教授 並に教室員各位に摩く御礼申し上げをす。

\section{文献}

1) D.E. Lea 著, 西脇安訳：放射線生物物理学, p. 54 岩波畫店, 東京, (1957).

2) L.J. Cole, M.C. Fischler, M.E. Ellis and V.P. Bond: Proc. Soc. Exp. Biol. \& Med., 80, 112, (1952).

3) L.O. Jacobson, E.L. Simmons, E.K. Mark and J.H. Eldredge: Science, 118, 510, (1951).

4) E. Lorenz, \& Uphoff, J.R. Reid and E. Schltom: J. Nat. Cancer Inst., 12, 197, (1951).

5) Louitit, 鯮柳武雄: 日本医事新啈 No. 1798, (昭 和 33 年 10 月) より

6) 岩川克信: 医学 14,（3)151, (1953).

7）岩川克娮：日本医事新報：No. 1588，4086（昭 和 29 年 10 月 2 日)

8）矢追多武，木村康夫：日本医事新報, No. 1568 （昭和 29 年 5 月 15 日） その他矢追秀武他：日本細 菌学会誌: 13, 660, (1958).

9) 日比谷寿夫 $(1 \sim 5$ 編): 日本小児科学会誌 59 , (6), 502 及び 509 ，(1955)，60，(1)，39 及 45，(1956).

10）上原偉男, 国延益弘：内科の領域 3, 133, (1955).

11）上原偉男：日本医事新誌 72, (9), 11.

12) E.W. Flosdorf: Freeze-drying (Drying by sublimation), Rein hold Publ. Corp. N.Y. (1949).

13) 根并外喜男：低温科学, 7, 149, 1951 .

14) H. Heinecke: Deutsch, Zeitschr. f. Chir, 78, 196, (1905).

15) 福島孝吉：日本放射線学会誌 $\mathbf{1 0}(2), 7,(1950)$.

16) 福島孝吉：日本放射線学会誌 $\mathbf{1 0}(5,6), 1$, (1950).

17）前田盛正：日本放射線学会誌 $\mathbf{1 3}(3), 152$, (1953).

81) E. Lorenz: Amer, J. Roent, Ra. Th. 63, 176, (1950), E. Lorenz et al. Am. J. physiol. 176, 297, (1954).
19) R. Rauer: Strahlentherapie 67, (1940).

20) M. Bloom and W. Bloom: J. Lab. and Clin. Med. 323, 654, (1947).

21）加藤周一：日本放射線学会誌, $10(1), 24,(1950)$.

22）原 邦郎：日本医事新報 No. 849, (昭和 13 年)

23）阿部知成：日本医放会誌， 18(7)，989, (1958).

24) K. Fuchenn: Strahlenther, 93, 307, (1954).

25）平田光夫：日本医放医誌， 14, 57, (1954).

26）真山周栄：日本医放会誌，13，212，(1953).

27）城戸正光：日本医放会誌，15，1046，(1956).

28）林 富栄：日本医放会誌，17，157，(1957).

29）山田要助：日本医放会誌，18(10), 1389, (1958).

30) 松村哲哉: 日本血液学会誌, 19(5), 564, (1956).

31) C. Lutwak-Mann \& F.W. Gunz: Biochem, J. 44, 111, (1949).

32) G.J. Pfalz: Med. Klin., 16, 637, (1929).

33) Hsii Ma: Am. J. Cancer. 39, 319, (1940).

34) W. Barns: Am. J. Roentgen, 49: 663, (1943).

35) 足立忠, 飯塚 鿆：日本医放会誌，14，309， (1954).

36) 岩本 映：日本医放会誌，14，308 㐀び 1914, (1937).

37）塚原国雄：実験医誌，21，1378 及び 1687，(1937).

38）金生富雄：日本医放会誌，18，1351，(1959).

39) Helber und Linser: Münch. Med. Woch., 689, (1905).

40) Deptovic: Povts chr. Geb. Röntgenstr., 36, (1927).

41) 渡辺太郎：日本レントゲン学会誌, 5(4), (1927).

42）西下創一：日本医放会誌，18，1193，(1958）ょり

43）亀田鬼輔, 真野豊雄: 日本医放会誌, 18, 1750, (1959).

44) 藤野守一：日本医会放会誌， 1, 1, (1933).

45) T.T. Trrentin: Proc. Soc. Exp. Biol. \& Med, 96, 139, (1957).

46）佐々通裕，尾霄越文亮：日血会誌，22，267, (1959).

47）大野敏夫：実験医誌， 11，1201，(1928).

48）大島啓志：日血会誌，15，268，(1952)，16，203， (1953), 17, 244, (1954).

49）棚橋文雄：日血会誌，23，107，(1938).

50) P.C. Nowell et al: Cancer Res. 16, 258, (1956). 


\section{Summary}

The measurement of the oxidation rate of bone marrow is important in order to know the grade of radiation injury and the course of recovery, because the oxidation rate of the bone marrow in the guinea pig shows remarkable decrease by a single whole body $\mathrm{X}$-ray irradiation and its recovery is gradual.

The subcutaneous injection of powdered young rabbits bone marrow every other day to the guinea pig which had been irradiated by $\mathrm{X}$ ray in doses of $300 \mathrm{r}$ at a time, significantly promate the recovery of oxidation in the bone marrow.

On the other hand, the injection of powdered human leucocytes shows no good effects, and the daily injection of powdered pig's bone marrow or powoered pig lymphocytes shows inhibitory action in the recovery from the acute radiation injury in the guinea pig.

Department of Pediatrics, Juntendo University, School of Medicine 